\title{
PENGARUH PEMBERIAN EKSTRAK BIJI PEPAYA (Carica papaya L.), EKSTRAK DAUN MIMBA (Azadiracta indica A. Juss ) SERTA CAMPURAN EKSTRAK BIJI PEPAYADAN EKSTRAK DAUN MIMBA TERHADAP GAMBARAN HISTOLOGI GINJAL DAN HATI MENCIT JANTAN (Mus musculus L)
}

\author{
Ervina $\mathbf{L}^{1)}$ dan Sukarjati ${ }^{2)}$ \\ ${ }^{1)}$ Mahasiswa Prodi Biologi F.MIPA Universitas PGRI Adi Buana \\ ${ }^{2)}$ Staf pengajar Prodi Biologi F.MIPA Universitas PGRI Adi Buana
}

\begin{abstract}
The aim of study is to investigate the toxicity effect of extract Carica papaya, Linn seeds extrof act, mimba leaf extract, and combination Carica papaya, Linn and mimba leaf extract of renal and liver histologi. Twenty one of adult male rats were devided into seven groups consisting of three animals each the rats in groups. The groups of control administrated aquadest orally, while Carica papaya, Linn extract (50, $100 \mathrm{mg} / \mathrm{kg}$ body weight), mimba leaf extract $(50,100 \mathrm{mg} / \mathrm{kg}$ body weight), and combination of Carica papaya, linn seeds extract and mimba leaf extract $(50,100 \mathrm{mg} / \mathrm{kg}$ body weight) were given for 35 day. Rats were sacrifived the 36 day liver and kidney were collected for histopatologycal observation. The observation result on kidney, hemorarhage, congestive, oedema, degeneration. The observation result on result liver proximal tubule degeneration, distal tubule degeneration, intestinal bleeding, glomerulonefritis. The result of this study extract Carica papaya, linn seeds extract, mimba leaf extract, and combination of Carica papaya, Linn and mimba leaf extract showed significant $(p<0,005)$ influence damaged of liver and kidney histology
\end{abstract}

Keyword : Carica papaya, linn seeds, mimba leaf, rats

\section{PENDAHULUAN}

Obat tradisional adalah obat jadi atau ramuan bahan alami yang berasadari tumbuhan, hewan, mineral, sediaan galenik atau campuran bahan - bahan tersebut yang secara tradisional telah digunakan untuk pengobatan berdasarkan pengalaman (Pramono, 2006).

Penggunaan bahan alam, baik sebagai obat maupun tujuan lain cenderung meningkat, terlebih dengan adanya isu back to nature. Obat tradisional dan tanaman obat banyak digunakan masyarakat menengah kebawah terutama dalam upaya preventif, promotif, rehabilitatif suatu penyakit. Sementara ini banyak orang beranggapan bahwa penggunaan tanaman obat atau obat tradisional tidak memiliki efek samping yang merugikan bila penggunaanya kurang tepat.

Secara tradisional biji pepaya (Carica papaya L.) dapat dimanfaatkan sebagai obat cacing gelang, bahan baku masuk angin dan sumber mendapatkan minyak dengan kandungan asam - asam lemak tertentu. Biji pepaya (Carica papaya L.) mengandung senyawa fitokimia seperti alkaloid, flavonoid, tanin, saponin. Senyawa fitokimia tersebut ternyata memiliki aktivitas menurunkan kadar kolesterol Low Density Lipid (LDL) dan meningkatkan High Density Lipoprotein (HDL). Oleh karena itu, biji pepaya (Carica papaya L.) dapat dijadikan sumber senyawa kimia yang dapat menghambat penumpukan kolesterol LDL untuk mengurangi penyakit jantung koroner (Tona dkk, 1998).

Selain pepaya (Carica papaya L.), tanaman mimba (Azadiracta indica A. Juss) juga merupakan tanaman obat. Pemberian ekstrak etanol daun mimba (Azadiracta indica A. Juss) dapat mempercepat kematian sel kanker prostate (PC-3) in vitro dengan menaikkan fragmentasi DNA dan menurunkan jumlah sel kanker, menurunkan protein Bel-2 (anti-apoptotic protein), serta menaikan protein Bax.

Senyawa - senyawa yang ada pada ekstrak biji pepaya atupun ekstrak daun mimba (Azadiracta indica A. Juss) bila dikomsumsi akan masuk dan ikut beredar dalam darah dan akan difiltrasi oleh ginjal. Ginjal (ren) merupakan organ filtrasi dan reabsorbsi darah. Pada batas - batas tertentu ginjal tidak dapat melakukan fungsinya dalam filtrasi dan reabsorbsi zat - zat terlarut dalam darah sehingga dapat menyebabkan 
kerusakan ginjal. Selain ginjal, hati juga merupakan organ penting dalam tubuh. Hati mengubah zat buangan dan bahan racun untuk mudah diekskresi dalam empedu dan urin. Seperti yang diketahui bahwa adanya peningkatan efektivitas pada dosis tertentu dapat meningkatkan efek toksik.

Secara toksikologi bahan yang berbahaya adalah suatu bahan (baik alami maupun sintesis, organik, maupun anorganik) yang karena komposisinya dalam keadaan, jumlah, dosis dan bentuk tertentu dapat mempengaruhi fungsi organ sehingga mengganggu kesehatan baik sementara, tetap atau sampai menyebabkan kematian. Suatu bahan yang dalam dosis kecil sudah dapat menimbulkan gangguan, akan lebih berbahaya apabila dalam dosis besar. Akan tetapi bahan yang aman pada dosis yang kecil kemungkinan dapat berbahaya atau toksik jika digunakan dalam dosis besar atau dalam waktu yang lama, demikian juga bila tidak tepat guna dan waktu penggunaannya (Pramono, 2006).

Sehubungan dengan hal tersebut, maka dilakukan penelitian terhadap gambaran histologi ginjal dan hati mencit (Mus musculus L) yang telah diberi ekstrak biji pepaya dan ekstrak daun mimba (Azadiracta indica A. Juss) ataupun kombinasi keduanya sehingga dapat diketahui batas aman penggunaan ekstrak biji papaya dan ekstrak daun mimba sebagai obat tradisional.

\section{MATERI DAN METODE PENELITIAN}

\section{Metode Penelitian}

Penelitian eksperimen ini dilaksanakan pada bulan februari-april 2016 bertempat di Laboratorium mikrobiologi Program Studi Biologi Fakultas Matematika da Ilmu Pengetahuan Alam Universitas PGRI Adi Buana Surabaya.

\section{Alat dan Bahan Penelitian}

Bahan dalam penelitian ini adalah ekstrak biji pepaya, ekstrak daun mimba, campuran ekstrak biji pepaya dan daun mimba, mencit jantan
Peralatan pengambilan sampel : alat otopsi, botol tempat hati dan ginjal, pemotretan : kamera, pembuatan preparat : pinset, pisau, gunting, mikrotom, pengamatan preparat : mikroskop cahaya, mikrofoto dan fiksasi jaringan : formalin $10 \%$, dehidrasi : alkohol 70\%, 80\%, 90\%, 95\%, 100\%, dealkoholisasi : hematoxilin eosin, Preparat : kaca objek + kaca penutup, entelan.

\section{Tahap Pelaksanaan Penelitian}

\section{Pembuatan Ekstrak Biji Pepaya Dosis 50 $\mathrm{mg} / \mathrm{kg}$ bb dan Dosis 100 mg/kg bb.}

Biji pepaya yang telah dikeringkan didalam oven dihaluskan. Ditimbang sebanyak 100 gr, kemudian direndam dalam 1 liter larutan etanol $70 \%$ selama 3 hari. Destilasi hingga larutan di labu destilas tersisa $500 \mathrm{ml}$. Ekstrak di keringkan dalam oven suhu $70^{\circ} \mathrm{C}$ hingga kering.

\section{a. Ekstrak Biji Pepaya dosis $50 \mathrm{mg} / \mathrm{kg}$ bb}

Diketahui berat badan mencit 27,9 gr maka : $50 \times 0,0279 \mathrm{mg}=1,395 \mathrm{mg}$. $1,395 \mathrm{mg}$ ekstrak biji pepaya di larutkan 1 $\mathrm{ml}$ aquadest

b. Ekstrak Biji Pepaya dosis $100 \mathrm{mg} / \mathrm{kg}$ bb

Diketahui berat badan mencit 27,9 gr maka : $100 \times 0,0279 \mathrm{mg}=2,79 \mathrm{mg}$. 2,79 mg ekstrak biji pepaya di larutkan dalam $1 \mathrm{ml}$ aquadest

\section{Pembuatan Ekstrak Daun Mimba Dosis $50 \mathrm{mg} / \mathrm{kg}$ bb dan Dosis $100 \mathrm{mg} / \mathrm{kg}$ bb.}

Daun mimba yang telah dikeringkan didalam oven dihaluskan. Ditimbang sebanyak 100 gr, kemudian direndam dalam 1 liter larutan etanol $70 \%$ selama 3 hari. Destilasi hingga larutan di labu destilas tersisa $500 \mathrm{ml}$. Ekstrak di keringkan dalam oven suhu $70^{\circ} \mathrm{C}$ hingga kering.

a. Ekstrak Daun Mimba dosis $50 \mathrm{mg} / \mathrm{kg}$ bb

Diketahui berat badan mencit 27,9 gr maka : 50 x 0,0279 $\mathrm{mg}=1,395 \mathrm{mg}$. $1,395 \mathrm{mg}$ ekstrak daun mimba di larutkan $1 \mathrm{ml}$ aquadest 
b. Ekstrak Daun Mimba dosis $100 \mathrm{mg} / \mathrm{kg}$ bb

Diketahui berat badan mencit 27,9 gr maka : $100 \times 0,0279 \mathrm{mg}=2,79 \mathrm{mg}$. 2,79 mg ekstrak daun mimba di larutkan dalam $1 \mathrm{ml}$ aquadest

\section{Pembuatan Campuran Ekstrak Daun Mimba dan Biji Pepaya Dosis 50 mg/kg bb dan Dosis $100 \mathrm{mg} / \mathrm{kg}$ bb.}

a. Dosis $50 \mathrm{mg} / \mathrm{kg}$ bb.

Ekstrak biji pepaya dosis $50 \mathrm{mg} / \mathrm{kg}$ bb dan ekstak daun mimba dosis 50 $\mathrm{mg} / \mathrm{kg}$ bb dicampur lalu di larutkan dalam $1 \mathrm{ml}$ aquadest

b. Dosis $100 \mathrm{mg} / \mathrm{kg}$ bb.

Ekstrak biji pepaya dosis $100 \mathrm{mg} / \mathrm{kg}$ bb dan ekstak daun mimba dosis 100 $\mathrm{mg} / \mathrm{kg}$ bb dicampur lalu di larutkan dalam $1 \mathrm{ml}$ aquadest

\section{Tahap Adaptasi Hewan Percobaan}

21 ekor mencit di letakkan pada kandang, selama 1 minggu diberi pakan dan minum secara add libtum. Setelah 1 minggu 21 ekor mecit dibagi menjadi 7 kelompok, yaitu P0 (Kelompok Kontrol), P1 (Kelompok mencit yang diberi ekstrak biji pepaya dosis $50 \mathrm{mg} / \mathrm{kg} \mathrm{bb}$ ),P2 (Kelompok mencit yang diberi ekstrak daun mimba dosis $50 \mathrm{mg} / \mathrm{kg}$ bb), P3 (Kelompok mencit yang diberi campuran ekstrak biji pepaya dan ekstrak daun mimba dosis $50 \mathrm{mg} / \mathrm{kg} \quad \mathrm{bb}$ ), $\quad \mathrm{P} 4$ (Kelompok mencit yang diberi ekstrak daun mimba dosis $100 \mathrm{mg} / \mathrm{kg} \mathrm{bb}$ ), P5 (Kelompok mencit yang diberi ekstrak daun mimba dosis $100 \mathrm{mg} / \mathrm{kg}$ bb), P6 (Kelompok mencit yang diberi campuran ekstrak biji pepaya dosis $100 \mathrm{mg} / \mathrm{kg}$ bb). Pemberian ekstrak dilakukan 1 kali dalam sehari. Pemberian perlakuan pada hewan coba dilakukan selama 35 hari

\section{Pembuatan Preparat Dan Pengamatan Kerusakan Histologi Ginjal dan Hati Mencit}

Sampling dilakukan pada hari ke 37 pada masing - masing kelompok.Tikus didekapitasi terlebih dahulu selanjutnya jaringan ginjal dan hati diambil. Fiksasi jarinfan dilakukan selama 24 jam dalam formalin $10 \%$ selama $24 \mathrm{jam}$. pemrosessan jaringan diawali dengan dehidrasi dengan menggunakan alkohol bertingkat kemudian clearing dengan xylol dan dilanjutkan dengan embedding dengan parafin. Blok jaringan yang didapat kemudian dipotong setebal 4 $\mu \mathrm{m}$ menggunakan mikrotom, yang selanjutnya dilakukan pewarnaan histokimia pada preparat jaringan terhadap sel - sel inflamasi yaitu dengan menggunakan pewarnaan hematoxilyn eosin.

Preparat jaringan hati dan ginjal dari 7 kelompok perlakuan yang sudah diwarnai histokimia diamati dibawah mikroskop cahaya. Skoring kerusakan histologi ginjal dan histologi hati diamati pada perbesaran 100x, 200x, dan 400x.

\section{Analisa Data Kerusakan Histologi Ginjal}

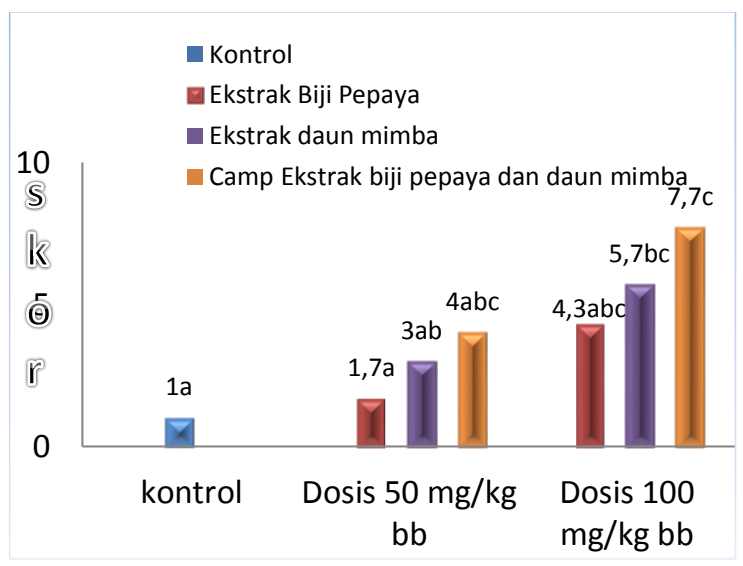

\section{Gambar 1 Diagram Rerata Kerusakan histologi Ginjal}

Dari gambar 1 menunjukkan bahwa nilai rata - rata kerusakan histologi ginjal kelompok kontrol tidak berbeda significan [p>0,05] dengan kelompok mencit yang diberi ekstrak biji pepaya dosis $50 \mathrm{mg} / \mathrm{kg} \mathrm{bb}$ $(\mathrm{P} 1)$, namun significan $[\mathrm{p}<0,05]$ dengan rata rata kerusakan histologi kelompok mencit yang diberi ekstrak daun mimba dosis 50 $\mathrm{mg} / \mathrm{kg}$ bb (P2), dan kelompok mencit yang 
diberi campuran ekstrak biji pepaya dan ekstrak daun mimba dosis $50 \mathrm{mg} / \mathrm{kg}$ bb (P3).

Nilai rata - rata kerusakan histologi ginjal kelompok mencit yang diberi ekstrak biji pepaya dosis $50 \mathrm{mg} / \mathrm{kg}$ bb (P1) significan $[\mathrm{p}<0,05]$ dengan kelompok mencit yang diberi ekstrak daun mimba dosis $50 \mathrm{mg} / \mathrm{kg}$ bb (P2), kelompok mencit yang diberi campuran ekstrak biji pepaya dan ekstrak daun mimba dosis $50 \mathrm{mg} / \mathrm{kg}$ bb (P3) dan kelompok mencit yang diberi campuran ekstrak biji pepaya dan ekstrak daun mimba dosis $100 \mathrm{mg} / \mathrm{kg}$ bb (P6), namun tidak berbeda significan $[p>0,05]$ dengan nilai rata - rata kerusakan histologi ginjal kelompok kontrol (P0).

Nilai rata - rata kerusakan histologi ginjal kelompok mencit yang diberi ekstrak daun mimba dosis $50 \mathrm{mg} / \mathrm{kg}$ bb (P2) tidak berbeda significan $[p>0,05]$ dengan kelompok mencit yang diberi campuran ekstrak biji pepaya dan ekstrak daun mimba dosis $50 \mathrm{mg} / \mathrm{kg}$ bb (P3), kelompok mencit yang diberi ekstrak biji pepaya dosis 100 $\mathrm{mg} / \mathrm{kg}$ bb (P4), kelompok mencit yang diberi ekstrak daun mimba dosis $100 \mathrm{mg} / \mathrm{kg}$ bb (P5), namun significan $[\mathrm{p}<0,05]$ dengan rata rata kerusakan histologi ginjal kelompok mencit yang diberi campuran ekstrak biji pepaya dan ekstrak daun mimba dosis 100 $\mathrm{mg} / \mathrm{kg}$ bb (P6), kelompok kontrol (P0) dan kelompok mencit yang diberi ekstrak biji pepaya dosis $50 \mathrm{mg} / \mathrm{kg}$ bb (P1).

\section{Nilai rata - rata kerusakan histologi ginjal kelompok mencit yang diberi campuran ekstrak biji pepaya dan ekstrak daun mimba dosis $100 \mathrm{mg} / \mathrm{kg}$ bb (P6) $[\mathrm{p}<0,05]$ significan dengan kelompok kontrol (P0), kelompok mencit yang diberi ekstrak biji pepaya dosis $50 \mathrm{mg} / \mathrm{kg}$ bb (P1), dan kelompok mencit yang diberi ekstrak daun mimba dosis $50 \mathrm{mg} / \mathrm{kg}$ bb (P2).}

\section{Analisa Data Kerusakan Histologi Hati}

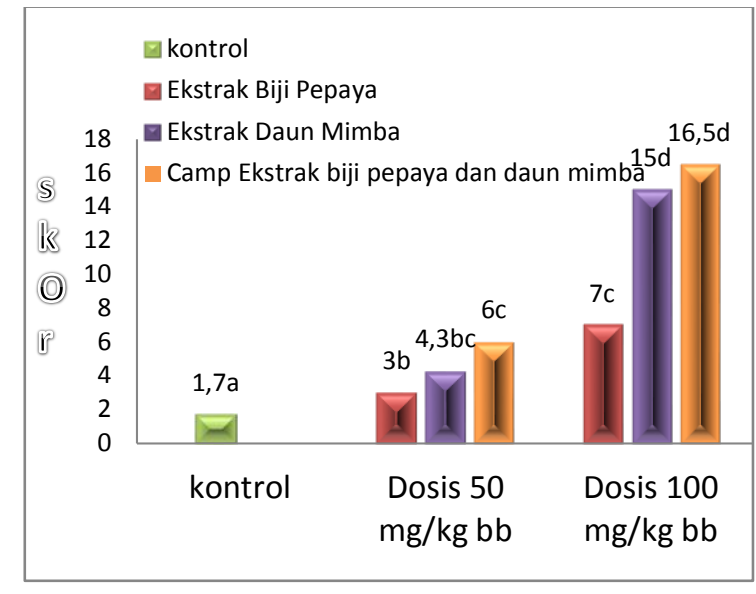

\section{Gambar 2 Diagram Batang Rerata Kerusakan Histologi Hati}

Gambar 2 menunjukkan bahwa pemberian ekstrak biji pepaya, ekstrak daun mimba, serta campuran ekstrak biji pepaya dan daun mimba berpengaruh terhadap kerusakan histologi hati mencit. Nilai rata rata kerusakan histologi hati kelompok kontrol (P0) significan $[\mathrm{p}<0,05]$ lebih rendah dibandingkan dengan kelompok mencit yang diberi ekstrak biji pepaya dosis $50 \mathrm{mg} / \mathrm{kg}$ bb (P1), kelompok mencit yang diberi ekstrak daun mimba dosis $50 \mathrm{mg} / \mathrm{kg}$ bb (P2), dan kelompok mencit yang diberi ekstrak daun mimba dosis $100 \mathrm{mg} / \mathrm{kg}$ bb (P5).

Nilai rata - rata kerusakan histologi hati kelompok mencit yang diberi ekstrak biji pepaya dosis $50 \mathrm{mg} / \mathrm{kg}$ bb (P1) tidak berbeda significan [p>0,05] dengan kelompok mencit yang diberi ekstrak daun mimba dosis 50 $\mathrm{mg} / \mathrm{kg}$ bb (P2) namun significan [p>0,05] dengan rata - rata kerusakan histologi hati kelompok kontrol, kelompok mencit yang diberi campuran ekstrak biji pepaya dan ekstrak daun mimba dosis $50 \mathrm{mg} / \mathrm{kg}$ bb (P3), kelompok mencit yang diberi ekstrak biji pepaya dosis $100 \mathrm{mg} / \mathrm{kg}$ bb (P4), kelompok mencit yang diberi ekstrak daun mimba dosis $100 \mathrm{mg} / \mathrm{kg}$ bb (P5), dan kelompok mencit yang diberi campuran ekstrak biji pepaya dan ekstrak daun mimba dosis $100 \mathrm{mg} / \mathrm{kg}$ bb (P6).

Nilai rata - rata kerusakan histologi hati kelompok mencit yang diberi ekstrak daun mimba dosis $50 \mathrm{mg} / \mathrm{kg}$ bb (P2) tidak berbeda significan [p>0,05] dengan kelompok mencit yang diberi campuran ekstrak biji pepaya dan ekstrak daun mimba 
dosis $50 \mathrm{mg} / \mathrm{kg}$ bb (P3), kelompok mencit yang diberi ekstrak biji pepaya dosis 100 $\mathrm{mg} / \mathrm{kg}$ bb (P4) namun significan $[\mathrm{p}<0,05]$ dengan kelompok kontrol (P0), kelompok mencit yang diberi ekstrak biji pepaya dosis $50 \mathrm{mg} / \mathrm{kg}$ bb (P1), kelompok mencit yang diberi ekstrak daun mimba dosis $100 \mathrm{mg} / \mathrm{kg}$ bb (P5), dan kelompok mencit yang diberi campuran ekstrak biji pepaya dan ekstrak daun mimba dosis $100 \mathrm{mg} / \mathrm{kg}$ bb (P6).

\section{PEMBAHASAN}

Hasil analisis preparat histopatologi kelompok mencit yang diberi ekstrak biji pepaya dosis $50 \mathrm{mg} / \mathrm{kg}$ bb (P1) secara statistik tidak berbeda significan $[\mathrm{p}<0,05]$ dengan kelompok P0 (Kontrol). Pada kelompok P0 dan kelompok P1 sama - sama terjadi degenerasi. Degenerasi sel atau kemunduran sel adalah kelainan sel yang terjadi akibat cedera ringan (Wulandari, 2007). Cedera ringan yang mengenai struktur dalam sel seperti mitokondria dan sitoplasma akan mengganggu metabolisme sel. Kerusakan ini sifatnya reversible artinya bisa diperbaiki apabila penyebabnya segera dihilangkan (Wulandari, 2007). Degenerasi tubulus proksimal pada ginjal kelompok P0 dapat diakibatkan karena lamanya tenggang waktu antara kematian mencit dengan proses otopsi. Gambaran histologik ginjal lebih dari 15 menit postmortem menunjukkan mulai tampak degenerasi hidropik sebagian kecil tubulus proksimal tetapi kapsul Bowman dan tubulus distal masih tampak normal (Wahyono, 2007). Pada proses postmortem, ginjal lekas mengalami autolisis yang terutama ditemukan pada epitel tubulus ontorti yang secara mikroskopis sangat menyerupai tanda - tanda degenerasi, selain itu kerusakan pada histologi ginjal dapat disebabkan oleh zat toksik dari lingkungan baik yang terkandung dalam makanan, air, udara, faktor stres tikus, serta faktor internal yaitu daya tahan dan kerentanan tikus (Oktavia, 2010). Beberapa faktor tersebut dapat meningkatkan stres oksidatif.Stres oksidatif merupakan kondisi dimana produksi radikal bebas atau oksigen reaktif melebihi sistem pertahanan tubuh.Radikal bebas yang tidak dinetralisir dapat menimbulkan kerusakan pada sel atau komponen sel (Brilyan, 2011).Sel cenderung mempertahankan lingkungan dan intraselnya dalam rentang parameter fisiologik yang relatif sempit, sel mempertahankan homeostasis normalnya.Ketika mengalami sress fisiologik, sel mengalami jejas.Dalam batas waktu tertentu cidera bersifat reversible dan sel kembali ke kondisi stabil. Apabila terjadi stress berat maka terjadi cidera ireversible dan sel akan mati. Tidak adanya perbedaan bermakna terhadap kontrol bisa disebabkan oleh jejas sel yang berlebihan dan menetap (Lu, 1995). Sedangkan degenerasi sel pada kelompok kelompok mencit yang diberi ekstrak biji pepaya dosis $50 \mathrm{mg} / \mathrm{kg}$ bb (P1) dapat disebabkan karena zat toksik dari ekstrak biji pepaya. Ekstrak biji pepaya mengandung glucosinolat yang merupakan bagian dari glucosida yang mengandung gugus triterpenoid dan steroid (Brilyan, 2011). Pemberian senyawa tertentu yang mengandung zat toksik memberikan beban berlebih terhadap ginjal terutama di daerah kapsul Bowman sebagai filter utama (Lu, 1994)..Pada kelompok P1 juga terjadi pendarahan.Perdarahan yang terjadi akibat masuknya zat toksik kedalam jaringan ginjal, mengakibatkan timbulnya jejas pada sel endotel dinding pembuluh darah.Sel endotel normal mempunyai fungsi sebagai anti trombosit, anti koagulan, dan pro koagulan.Sehingga pada keadaan normal trombosit mengalir dalam aliran darah dengan tidak melekat pada endotel.Namun, ketika terjadi jejas sel endotel, fungsi anti trombosit tidak berfungsi, sehingga terjadi perlekatan trombosit pada sel endotel pembuluh darah. Pada tempat terjadinya jejas sel endotel, darah keluar kedalam jaringan interstisial sehingga trombosit akan menempel pada endotel pembuluh darah menyebabkan penyempitan lumen pembuluh darah sehingga terjadi pembendungan aliran darah, dan akhirnya pembuluh darah pecah (Angelina, 2008).

Hasil analisis kerusakan histopatologi ginjal padakelompok mencit yang diberi ekstrak daun mimba dosis $50 \mathrm{mg} / \mathrm{kg}$ bb (P2) secara statistik tidak menunjukkan perbedaan yang significant terhadap kelompok mencit yang diberi campuran ekstrak biji pepaya dan ekstrak daun mimba dosis $50 \mathrm{mg} / \mathrm{kg}$ bb (P3), kelompok mencit yang diberi ekstrak biji pepaya dosis $100 \mathrm{mg} / \mathrm{kg}$ bb (P4), kelompok mencit yang diberi ekstrak daun mimba dosis 
$100 \mathrm{mg} / \mathrm{kg}$ bb (P5), kelompok mencit yang diberi campuran ekstrak biji pepaya dan ekstrak daun mimba dosis $100 \mathrm{mg} / \mathrm{kg}$ bb (P6) namun bila dilihat dari rerata kerusakan histologi ginjal, dapat dilihat adanya peningkatan kerusakan histologi ginjal yang dimulai dari kelompok P2, dan makin meningkat pada kelompok P3, P4, hingga kelompok P5. Peningkatan kerusakan histologi ini seiring dengan peningkatan jumlah dosis dan jenis ekstrak yang diberikan pada tiap kelompok perlakuan.

Kerusakan yang terjadi pada kelompok mencit yang diberi ekstrak daun mimba dosis $50 \mathrm{mg} / \mathrm{kg}$ bb (P2) meliputi adanya kerusakan tubulus proksimal serta peningkatan skor perdarahan interstinal pada jaringan ginjal sedangkan kelompok mencit yang diberi campuran ekstrak biji pepaya dan ekstrak daun mimba dosis $50 \mathrm{mg} / \mathrm{kg}$ bb (P3) mengalami kerusakan pada tubulus proksimal dan kerusakan pada tubulus distal. Tubulus merupakan bagian ginjal yang paling banyak dan paling mudah mengalami kerusakan pada kasus nefrotoksik. Hal ini dapat terjadi karena adanya akumulasi bahan - bahan toksik pada segmen ini dan karakter tubulus yang memiliki epitel yang lemah dan mudah bocor (Manggarwati et al, 2010). Kerusakan pada tubulus proksimal berhubungan dengan fungsi dasarnya sebagai tempat absorbsi dan sekresi aktif (Lu, 1995).Setelah filtrasi zat toksik dan sisa metabolit oleh glomerulus, tempat ultra filtrat dari plasma darah terbentuk. Pada pemberian zat toksik dalam jangka waktu tertentu, glomerulus tidak mampu lagi mengakumulasi zat toksik, sehingga permiabiitasnya bertambah, sehingga molekul dengan berat molekul yang tinggi lolos dan ikut sampai pada tubulus dengan kadar abnormal. Zat metabolit dan bahan toksik dapat menyebabkan gangguan pada organel mitokondria yang menghasilkan energi ATP, ATP dibutuhkan agar pompa natrium $\left(\mathrm{Na}^{+}\right)$berjalan lancar.Bila ATP tidak dihasilkan maka $\mathrm{Na}^{+}$bersifat menarik air, sehingga terakumulasi kedalam sel, akibatnya sel membengkak dan sitoplasma nampak keruh (Lu, 1995). Kerusakan pada tubulus proksimal berimbas pada kerusakan tubulus distal karena pada tubulus distal terjadi pemekatan urin.
Seiring dengan peningkatan dosis, maka terjadi pula peningkatan kerusakan jaringan ginjal dari kelompok perlakuan. Dosis merupakan hal utama yang menentukan apakah suatu zat kimia bersifat racun atau tidak (Wulandari, 2007). Pada kelompok mencit yang diberi ekstrak biji pepaya dosis $100 \mathrm{mg} / \mathrm{kg}$ bb (P4) dan kelompok mencit yang diberi ekstrak daun mimba dosis $100 \mathrm{mg} / \mathrm{kg}$ bb (P5) terjadi peningkatan perdarahan interstial, peningkatan degenerasi tubulus proksimal, dan degenerasi tubulus distal, dan glomerulonefritis. Telah diketahui bahwa ekstrak dari biji pepaya dan ekstrak daun mimba mengandung alkaloid dan saponin.Saponin dapat menyebabkan hemolisis sel darah merah dan iritasi gastrointertinal (Marusin, 2001).Selain saponin, metabolit yang bersifat toksik yaitu alkaloid.Alkaloid memerlukan waktu yang lama untuk diekresikan dan dimetabolisme, sehingga kontak alkaloid dengan sel ginjal lebih lama (Wahyono, 2007).Peningkatan dosis dan lama waktu pemaparan suatu zat toksik terhadap suatu organ, dapat meningkatkan kerusakan jaringan organ tersebut (Price, 2002).

Glomerulonefritis yang terjadi pada kelompok mencit yang diberi ekstrak biji pepaya dosis $100 \mathrm{mg} / \mathrm{kg}$ bb (P4) dan kelompok mencit yang diberi ekstrak daun mimba dosis $100 \mathrm{mg} / \mathrm{kg}$ bb (P5) akibat kelainan reaksi imun yang merusak glomerulus. Pemberian ekstrak biji pepaya dan ekstrak daun mimba dengan berbagai zat yang terkandung didalamnya, setelah masuk kedalam ultra filtrat glomerulus, zat - zat tersebut dikenali oleh glomerulus sebagai antigen, sehingga timbul reaksi antibodi dan antigen yang akan membentuk komplek imun yang tidak dapat larut dan terjerat didalam glomerulus, terutama dibagian membran basal glomerulus. Adanya endapan komplek imun tersebut akan mengakibatkan glomerulus mengalami reaksi radang atau glomerulonefritis .

Pada kelompok mencit yang diberi campuran ekstrak biji pepaya dan ekstrak daun mimba dosis $100 \mathrm{mg} / \mathrm{kg}$ bb (P6) terjadi peningkatan pada setiap parameter.Kerusakan ini terjadi akibat ketidakmampuan sel ginjal dalam melakukan 
metabolisme karena peningkatan kerusakan yang terjadi pada jaringan ginjal. Penggunaan campuran ekstrak biji mimba dan ekstrak daun mimba dalam menimbulkan efek aktifitas yang lebih kuat sehingga juga menimbulkan kerusakan pada organ ginjal ( Wiratmo, 2014).

Hati merupakan organ tubuh yang paling rentan terhadap bahan kimia toksik (Vita, 2011). Hati merupakan tempat xenobiotik (senyawa asing) mengalami metabolisme dan detoksifikasi biotransformasi atau detoksikasi merupakan proses yang pada umumnya mengubah senyawa awal metabolit, kemudian membentuk konjugat yang lebih mudah larut dalam air dan mudah diekskresikan.

Pada penelitian ini, kerusakan jaringan histopatologis hepar kelompok kontrol (P0) tidak berbeda significan dengan kelompok mencit yang diberi ekstrak biji pepaya dosis $50 \mathrm{mg} / \mathrm{kg}$ bb (P1). Hal ini terlihat dari kerusakan jaringan yang diamati, dimana kerusakan yang terjadi berupa degenerasi. Degenerasi merupakan perubahan morfologi sel yang bersifat reversible. Perubahan ini ditandai dengan adanya akumulasi beberapa produk dari hasil metabolisme sel seperti air, lemak, protein, glikogen dan sebagainya. Kondisi seperti ini dapat dikatakan adanya akumulasi patologis intraseluler (Lu, 1995).

Degenerasi yang terjadi pada kontrol dapat disebabkan dari faktor stres yang dialami mencit. Pada saat stress, hormon kortisol akan meningkat dan menekan ploriferasi leuksit, sehingga imunitas tubuh berkurang. selain itu terjadi penekanan sel Natural Killer (NK), sehingga sel NK sukar masuk ke hepar. Hal ini menyebabkan sel NK tidak dapat membunuh virus dan benda asing pada hati, sehingga resiko kerusakan hati meningkat. (Lu, 1995). Terjadinya degenerasi pada kelompok mencit yang diberi ekstrak biji pepaya dosis $50 \mathrm{mg} / \mathrm{kg} \mathrm{bb}$ (P1) akibat dari zat toksik dari senyawa aktif ekstrak biji pepaya yang diberikan secara peroral selama 35 hari. Sesuai dengan penjelasan Lu (1995), bahwa hati sangat rentan terhadap pengaruh zat kimia dan menjadi organ utama dari zat beracun. Hal ini terjadi karena sebagian besar racun atau zat toksik yang masuk kedalam tubuh setelah diserap oleh sel akan dibawa ke hati oleh vena porta hati, sehingga hati berpotensi mengalami kerusakan.

Kerusakan jaringan hati kelompok mencit yang diberi ekstrak biji pepaya dosis $50 \mathrm{mg} / \mathrm{kg}$ bb (P1) berbeda significant dengan dengan kelompok mencit yang diberi ekstrak biji pepaya dosis $100 \mathrm{mg} / \mathrm{kg}$ bb (P4). Peningkatan dosis dari ekstrak yang diberikan dapat meningkatkan kerusakan histologi hati (Gan dkk, 1997). Peningkatan kerusakan hepar dapat dilihat pada tabel skoring kerusakan histologi hepar. Keadaan ini juga terjadi pada kelompok perlakuan yang lain, dimana kerusakan histologi hati kelompok mencit yang diberi ekstrak daun mimba dosis $50 \mathrm{mg} / \mathrm{kg}$ bb (P2) berbeda significant dengan kelompok mencit yang diberi ekstrak daun mimba dosis $100 \mathrm{mg} / \mathrm{kg}$ bb (P5), kelompok mencit yang diberi campuran ekstrak biji pepaya dan ekstrak daun mimba dosis $50 \mathrm{mg} / \mathrm{kg}$ bb (P3) berbeda significan dengan kelompok mencit yang diberi campuran ekstrak biji pepaya dan ekstrak daun mimba dosis $100 \mathrm{mg} / \mathrm{kg}$ bb (P6). Peningkatan kerusakan histologi hati dimulai dari degenerasi dan makin meningkat menjadi kongesti, hemoragi, oedema, dan radang.

Kerusakan jaringan hati pada kelompok mencit yang diberi ekstrak daun mimba dosis $50 \mathrm{mg} / \mathrm{kg}$ bb (P2), secara statistik tidak berbeda significant dengan kelompok P1dan kelompok P3. Meskipun pada dosis yang sama, kerusakan histologi hati pada tiap kelompok berbeda. Hal ini dipengaruhi oleh kandungan senyawa aktif dari masing - masing ekstrak. Tiga senyawa aktif dalam ektrak biji pepaya yaitu saponin, triterpenoid, dan tanin merupakan zat yang bersifat polar sehinga mudah dimetabolisme oleh hati(Brilyan, 2011). Senyawa aktif dari daun mimba adalah flavonoid, fenolik, triterpenoid, dan tanin. Namun salah satu kandungan ekstrak biji pepaya yaitu nimbolide bersifat toksik bagi tubuh (Brilyan, 2011). Selain itu, flavonoid pada ekstrak daun mimba dapat menghambat enzim sitokrom P450. Adanya hambatan pada enzim tersebut dapat meningkatkan bioavailabilitas zat toksik sehingga menimbulkan efek dari zat toksik dan meningkatkan toksisitasnya dalam tubuh 
(Budiono, 2000). Kombinasi dari kandungan ekstrak daun mimba dan biji pepaya dapat meningkatkan efek aktivitas yang lebih kuat (Wiratmo, 2014), sehingga lebih meningkatkan kerusakan histologi hati, oleh sebab itu kerusakan histologi hati pada kelompok perlakuan kombinasi ekstrak lebih berat dbandingkan dengan kelompok perlakuan lain.

\section{SIMPULAN DAN SARAN}

\section{Simpulan}

1. Ada pengaruh pemberian ekstrak biji pepaya, ekstrak daun mimba, serta campuran ekstrak biji pepaya dan daun mimba pada dosis $50 \mathrm{mg} / \mathrm{kg}$ bb dan dosis $100 \mathrm{mg} / \mathrm{kg}$ bb mencit terhadap kerusakan histologi hati mencit.

2. Ada pengaruh pemberian ekstrak biji pepaya, ekstrak daun mimba, serta campuran ekstrak biji pepaya dan daun mimba pada dosis $50 \mathrm{mg} / \mathrm{kg}$ bb dan dosis $100 \mathrm{mg} / \mathrm{kg}$ bb mencit terhadap kerusakan histologi ginjal mencit.

3. Peningakatan dosis dan jenis ekstrrak mempengaruhi kerusakan histologi ginjal dan hati

\section{Saran}

Penggunaan ekstrak biji pepaya dan ekstrak daun mimba serta campuran ekstrak biji pepaya dan daun pepaya pada dosis $50 \mathrm{mg} / \mathrm{kg}$ bb dan dosis $100 \mathrm{mg} / \mathrm{kg}$ bb mencit menimbulkan kerusakan pada histologi ginjal dan hati mencit sehingga disarankan pengurangan dosis pada penggunaan ekstrak biji pepaya dan ekstrak daun mimba serta campuran ekstrak biji pepaya dan daun pepaya

\section{REFERENSI}

Angelina, M., Hartati, S., Dewijanti, I.D., Banjamahor, S.D.S., dan Meilawati, L., 2008. Penentuan LD50 Daun Cinco (Cyclea barbata Miers) pada mencit. Makara Sains. Vol 12 (1) : 23 26
Brilyan, A. 2011. Gambaran Histopatologi Hepar Mencit Dengan Paparan Candica albicans Yang Diterapi Ekstrak Air Daun Mimba (Azadiracta indica). Universitas Airlangga. Surabaya.

Budiono, B dan Herwiyati, S. 2000. The Histologi cal Structure Of Liver Of Rats After Comsuming Ekstrac Of Lantoro Leaf And Green Tea (Leucaena leucochepala). Jurnal Kedokteran YARSI. 8(2) : 16 - 24.

Dorland. Kamus Kedokteran Edisi 30. 2008. Jakarta: EGC p.1887

Drake et al. Gray's Anatomy For Students 2nd Edition. 2010. Philadelphia:

Elsenvier. P.355 -59.

Ganong WF. 2003. Fisiologi Kedokteran. Djauhari W, Dewi I, Minarma S, Penerjemah Yoyakarta: Universitas Gajah Mada Press.

Guyton, A. C. 1994. Buku Ajar Fisiologi Kedokteran. Edisi 7. Kedokteran EGC. Jakarta

Guyton, A.C. 1995. Fisiologi Manusia dan Mekanisme Penyakit (Edisi 3). Terjemahan P. Andrianto. Penerbit Buku Kedokteran EGC. Jakarta.

Hanifah, L. 2008. Pengaruh Pemberian Buah Pepaya (Carica papaya. L) Terhadap Tingkat Nekrosis Epitel Glomerulus dan Tubulus Ginjal Mencit (Mus musculus) yang diInduksi CCL4 (Karbon Tetraklorida). [Skripsi]. Universitas Islam Negeri Malang. Malang.

Kumar, Abbas, Fausta, Micthell. Basic Pathology 8th Edition. 2007. Jakarta: EGC P. 595 - 97.

Lu FC. 1995. Toksikologi Dasar Asas. Organ Sasaran Dan Penilaian Resiko Ed ke-2. Jakarta: UI Press.

Lohiya, N.K., Manivanan, B., Mishra, P.K.,Pathak, N., Bhande, S.S., dan Panneerdoss, S. 2002. Chloroform Ekstrac Of Carica papaya Seed Induces Long - Term Reversible Azoospermia in Langur Monkey. Asian Journal Of Andrologi . Vol 4(1): $17-26$.

Marusin, N., W. Munir dan Febrina. 2001. Pengaruh Lama Pemaparan $\mathrm{Pb}$ 
Terhadap Gambaran Histologi Ginjal Mencit Putih (Mus musculus L).

Price, S.A. dan L. M. Wilson. 1992. Patofisiologi Konsep Klinis ProsesProses Penyakit. Buku 2. (Edisi 4). Terjemahan P. Anugerah. Penerbit Buku Kedokteran EGC. Jakarta

Wahyono, Hakim, L., Nurlaila, Sulistio, M., Ilyas,R. 2007. Uji Toksisitas Akut Ekstralk Etanolik Terstandar dari kulit akar senggugu. Majalah Farmasi Indonesia . Vol 18 (1): 1 - 7.

Wulandari, T., Harini, M, Listyawati, S. 2007.Pengaruh Ekstrak Daun Sambiloto (Andrographis paniculata) terhadap struktur mikroanatomi hepar dan kadar Glutamat Piruvat Transaminase Serum Mencit (Mus musculus) Yang Terpapar Diazinon.

Wiratmo, 2014.Pengembangan Formula Jamu Antifertilitas Pria Dari Kombinasi Fraksi Aktif Biji Saga (Abrus precatorius) Dan Biji Pepaya (Carica papaya). Universitas Jember. Jember 